\title{
The Free Public Library, Auckland, N.Z.
}

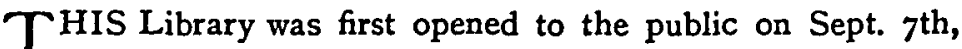
1880 , and occupied a somewhat unpretentious building in an obscure part of the town. It contained at that time about 5,300 volumes, made up from the Provincial Council Library, and the Library of the Mechanics' Institute, and it claims to be the first library supported by rates in this part of the world. A wealthy citizen, Mr. Edward Costley, dying in the early part of 1883 , left a munificent bequest of something like $\ell$ I2, I50 to be expended upon the library, and this produces an income of about $£ 800$ per annum. On the $4^{\text {th }}$ of June, 1885 , the foundation stone of the present magnificent building, known as the Free Public Library and Art Gallery, was laid; towards the end of 1886 the City Council purchased 1,700 volumes, making a total of 7,000 volumes; and on the 27th of March, 1887 , the new building was formally opened to the public.

Sir George Grey, K.C.B. (to whom the public of Auckland will for ever be indebted), having added his superb collection of books, to the number of 9,000, the total number of volumes in the library at the end of 1887 amounted to about 16,000 . Owing to this generosity on the part of Sir George Grey, Auckland now boasts of a library unequalled in intrinsic value south of the equator, and it must be a matter of no small surprise to tourists and visitors from Europe and America, to see in so comparatively young a country MSS, of the middle ages, of which there are no copies or duplicates in existence. These MSS., dating from the roth century, and some 53 in number, are in Latin, Greek, Ethiopic, and Arabic, and may be considered priceless.

To mention a few of them-first and foremost perhaps are the Four Gospels, written in Greek, and said to be from Mount Athos.

Aristotle's Metaphysica, end of the $14^{\text {th }}$ century, is a splendid manuscript, containing minute marginal notes, in what might almost be called microscopical writing.

The Sonnets of Petrarch, a MS. of the 15th century, beautifully illuminated with miniature portraits.

Gregorius Magnus, a large square folio in the original binding. Concerning this MS. Dr. Adam Clarke says-"From the binding it appears that this volume formerly belonged to Henry 
V., King of England. The leather is embossed with various devices. On the right side there is a square compartment, divided into sixteen parts, in each of which, in a lozenge, there is a rose. In a square contained within this there is another square, in the centre of which is the Lancastrian rose, and in a scroll round about the following legend-

\section{' Hec rosa virtutis de celo missa sereno Eternum florens regia sceptra feret.'}

The scroll and rose are supported by two angels kneeling; over the head of the one, on the left appear the sun and stars, and over that on the right the moon and stars are represented, and at the bottom-H Rex V. On the left hand side, in a square as before, there is another, in which there is a large shield, containing the Arms of England and France, quartered, three fleur de lis, and three lions passans guardans. The shield is sur. rounded with a royal crown, and is supported by a greyhound, more like a wolf, on the right, and a griffin on the left. Over the head of the griffin appear the sun and stars, and over the head of the greyhound or wolf, the moon and stars. At the bot. tom of the shield is an H. V., the initials of Henry V. On each cover, at the oblong end of the square, which contains the scroll and arms, are two compartments, four on each cover, in each of which a pelican is represented, with her young in a nest, which shc is feeding with her blood. As Henry V. came to the throne in 1413 , and died in 1422 , this MS. must have been bound within that period, about 400 years ago."

Coming down to later times we have the documents known as the Cromwell Documents, contäining an original treat: concluded by Richard Cromwell in 1659, and bearing the signatures and seals of Lambert, Wal. Strickland, Lyle, anci other men of historical fame; included in the documents is the original correspondence which passed between Thurloe, the English statesman of the time, and Sir P. Meadows, 1657-1658. There arc also two very curious French documents, one a passport dated Versailles, 1783 , and bearing the signature of Louis XVI., the other a warrant on the French treasury, with the signature of Marie Antoinette. Last, but not least perhaps, among the ISS., may be mentioned the journal of Capt. James Cook, dated 1769.1770, in the hand-writing of Capt. Cook; this of course is of special interest to all New Zcalanders.

In the section alloted to early printed books, of which there 
are a great number in the Grey Collection, is a splendid copy of St. Augustine's De Civitate Dei, printed by Wensżler, at Bale, in I479 and is probably next to the Editio Princeps. This Library which may be said to be the only one in the Southern Hemisphere which has in its possession three works printed by William Caxton, the father of English printing; the Polycronicon, 1482 , is probably the most valuable of the three Caxtons in the Auckland Library; it is in splendid preservation, the initial letters of the chapters, the dates, paragraph marks, \&c., are all carefully filled in with red ink, which remains still quite bright and clear. Next in value is the Golden Legend, printed in 1483; this copy has been re-bound, and the sheets have been most carefully treated, evidently by some skilled person. There are 449 printed folios, with three blanks. No copy yet found is perfect, and the Auckland Golden Legend wants both the beginning and the end. The third work of Caxton's is the Boke of Eneydos, "compyled by Vyrgyle," 1490. The book is in fine condition; the type is large and easily read, when the eye has become accustomed to the forms of the letters and the old fashioned spelling; it is printed in Caxton's No. 6 type. There is no title page. Here also may be seen a copy of the majestic verse of Chaucer, in almost as good condition, and nearly as fresh as when it came from the press of Richard Pynson, in 1493 . There is, however, an earlier work of Pynson's, The Statutes of Henry VII., "Emprynted by my Richard Pynson, I 479."' But to enumerate individually all the early printed works in the Grey Collection would exceed the limits of an outline sketch.

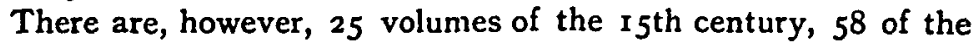
I6th century, $4^{\circ}$ of the $17^{\text {th }}$ century, and 20 of the early part of the isth century.

The library is peculiarly rich in philology, no less than 216 different languages and dialects being represented, principally in the theological and philological departments.

There are also a great number of pamphlets; these are bound up in volumes, and form a section of their own in which there are 166 volumes. The autograph letters in the Grey Collection amount to about 7,000 , and among a few of the mast prominent may be nentioned the autographs of Lord Nelson, Herschel the astronomer, Dr. Livingstone, Capt. Sturt the Australian 
explorer, Florence Nightingale, the Duke of York, Thomas Carlyle, \&c., \&c.

Owing to the recent gifts of Sir George Grey, donations from other sources, purchases, \&c., the library has greatly increased during the last year or so, and the total number of MSS., volumes, \&c., in the library at the present time is $20,239 .{ }^{x}$

\section{W. L. F. Covert,}

Assistant Librarian.

' We are informed by Mr. Petherick, the editor of The Torch, that, "Auckland is well off for public libraries, as in addition to the Free Library, it possesses also 'A Library for State School Teachers,' a 'Law Library' (attached to the Supreme Court), and 'The Auckland Institute and Museum.' The lastnamed contains over 3,000 volumes and tracts relating to, or issued in, New Zealand, and a larger number of a scientific character, mostly the gift of the late J. T. MacKelvie, Esq. This library shares also in the Costley bequest to the city of Auckland."

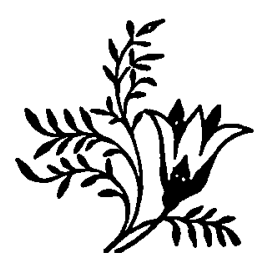

